International Journal of Current Advanced Research

ISSN: O: 2319-6475, ISSN: P: 2319 - 6505, Impact Factor: SJIF: 5.995

Available Online at www.journalijcar.org

Volume 6; Issue 3; March 2017; Page No. 2745-2746

DOI: http://dx.doi.org/10.24327/ijcar.2017.2746.0095

Research Article

\title{
STUDY OF SEXUAL DIMORPHISM AND TOOTH SIZE VARIATION IN CANINES IN SOUTH INDIAN POPULATION
}

\author{
Manthra Prathoshni S., Yuvaraj Babu K and Karthick Ganesh
}

Saveetha Dental College, Chennai-600077

A R T I C L E I N F O

\section{Article History:}

Received $24^{\text {th }}$ December, 2016

Received in revised form $19^{\text {th }}$ January, 2017

Accepted $12^{\text {th }}$ February, 2017

Published online $28^{\text {th }}$ March, 2017

\section{Key words:}

Sexual Dimorphism And Tooth Size Variation

\begin{abstract}
A B S T R A C T
Sex determination is an important step in determining the biological profile of unidentified human remains. It is done using craniofacial morphology, tooth dimensions and DNA analysis. In addition, the resistance of teeth to postmortem insults render them as a valuable tool in forensic investigation. The existence of sexual dimorphism in permanent teeth is a known phenomenon.Among many methods, odontometrics is the easiest and accurate way of determining the sex of an individual in forensic sciences as some teeth namely canines, molars show sexual dimorphism.

The aim of this study is toanalyze the presence of sexual dimorphism in the mesiodistal diameter of permanent canine teeth in the samples of South Indian population and to determine the sex of an individual using dimensions of the canines in permanent dentition.The mesiodistal diameter of the canines were measured for 50 patients visiting Saveetha Dental College aged between 20 to 45 using manual vernier calipers. It was found that mesiodistal measurements of maxillary and mandibular canines of males than in females.
\end{abstract}

Copyright $\odot 2017$ Manthra Prathoshni S., Yuvaraj Babu K and Karthick Ganesh. This is an open access article distributed under the Creative Commons Attribution License, which permits unrestricted use, distribution, and reproduction in any medium, provided the original work is properly ritnd

\section{INTRODUCTION}

Sex determination is a very important tool in forensic science for determination of sex of unidentified remains. The study of teeth is of great interest to anthropologists, biologists, orthodontists and forensic scientists. [1]. The term sexual dimorphism refers to the differences in shape, size, stature and appearance of male and female parts [2]. This sexual dimorphism is more reliable and accurate in case of tooth dimensions.Sex differentiation in forensic investigation utilises craniofacial morphology, tooth dimensions and DNA analysis. [3]

Odontometrics plays an important role in sex determination. Since teeth are resistant to postmortal damage and decay, it is considered as a reliable tool for sex determination [4]. According to some studies, teeth are known to show sexual dimorphism. This is mainly based on comparison of tooth dimensions in males and females [5][6][7]. Crowns of permanent teeth are formed at an early stage and their dimensions remain unchanged during further growth and development, except in cases when specific changes and disorders in terms of functionality, pathology and nutrition can have affect on the normal dimensions of a tooth. Teeth were studied by several methods which include Moire's topography and Fourier's analysis and measurement of linear

*Corresponding author: Manthra Prathoshni S

Saveetha Dental College, Chennai-600077 dimensions, such as mesiodistal width, buccolingual width and incisocervical height [8].

According to Bossert and Marks and Krough, the canine teeth shows more dimorphism than any other teeth [9]. In addition to it, it has advantages like, it is the least affected teeth by periodontitis and least frequently extracted teeth [10]. The canine teeth are also more resistant to air and hurricane attacks, according to a study [11].

There are few studies which focussed on the sexual dimorphism in tooth of males and females in India including that of Rao et al. [12][13]. The objective of this study is to determine the existence of sexual dimorphism in maxillary and mandibular canines of males and females in South Indian population (Tamil Nadu).

\section{MATERIALS AND METHODS}

The study was carried out on 50 outpatients (25 males and 25 females) aged between 20 to 45 years visiting Saveetha Dental College, after obtaining consent from the patients. The mesiodistal diameter of each maxillary and mandibular canine of the subject is measured using manual vernier calipersand is tabulated for comparison.

\section{Mesiodistal diameter}

It is the distances between the mesial and distal surfaces of the tooth. In case of tooth rotation or malposition, it is measured between points on approximate surfaces of the crown where it 
was considered that contact with adjacent teeth would have normally occurred. It is measured using vernier calipers in millimetres.

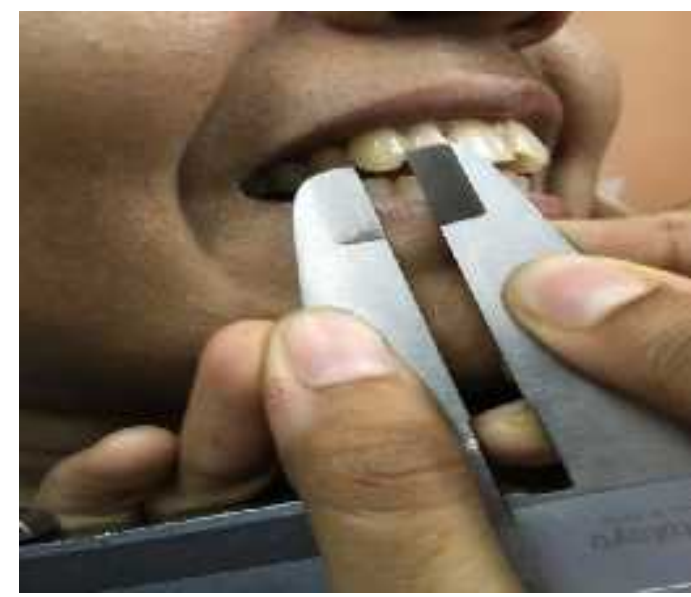

\section{RESULTS AND DISCUSSION}

The results of the study are given below:

The table 1gives the average of mesiodistal diameter of maxillary right canine (13), maxillary left canine (23), mandibular right canine (43) and mandibular left canine(33).

\begin{tabular}{cccc}
\hline Tooth & Range ( in mm) & $\begin{array}{c}\text { Mean of } \\
\text { Mesiodistal } \\
\text { diameter for men } \\
\text { ( in mm) }\end{array}$ & $\begin{array}{c}\text { Mean of } \\
\text { Mesiodistal } \\
\text { diameter for } \\
\text { women( in } \\
\text { mm) }\end{array}$ \\
\hline $\begin{array}{c}\text { Maxillary right } \\
\text { canine }\end{array}$ & $\begin{array}{c}8.13-0.67(\text { male) } \\
0.52-6.39 \text { (female) }\end{array}$ & 8.17 & 7.46 \\
$\begin{array}{c}\text { Maxillary left } \\
\text { canine }\end{array}$ & $\begin{array}{c}8.07-0.71 \text { (male) } \\
0.51-6.61(\text { female) } \\
5.96 \text { to } 6.03\end{array}$ & 8.07 & 7.45 \\
$\begin{array}{c}\text { Mandibular right } \\
\text { canine }\end{array}$ & $\begin{array}{c}\text { (male and female) } \\
0.51 \text { to } 6.09\end{array}$ & 6.98 & 6.48 \\
$\begin{array}{c}\text { Mandibular left } \\
\text { canine }\end{array}$ & $\begin{array}{c}\text { (male and female) } \\
\text { (mand }\end{array}$ & 6.99 & 6.47 \\
\hline
\end{tabular}

The sexual dimorphism exhibited in canines are used in determination of sex of unidentified remains in cases where the bones are destroyed.

Ditch and Rose were the first to prove that teeth diameters can be successfully used in sex determination of unidentified remains [14]. Chromosomes responsible for the sexual difference are in direct connection to growth and development of teeth.

In this study it was seen that mesiodistal diameter of maxillary canines were significantly greater in males than in females. According to study by Mohammed QAR et al., the mesiodistal diameter range for maxillary canines in males was found to be 0.61-6.99 mm(right) and 0.53-7.09 $\mathrm{mm}$ ( left) and for females, the rangeis $0.52-6.35 \mathrm{~mm}$ (right) and 0.51 $6.61 \mathrm{~mm}($ left). [7][15]

The range for male maxillary right and left canines is found to be 0.66 to $0.81 \mathrm{~mm}$ and females had range of 0.61 to $7.80 \mathrm{~mm}$. In case of mandibular right and left canines, the range for the males is found to be 5.96 to $6.03 \mathrm{~mm}$ and for females, the range was 0.51 to $6.09 \mathrm{~mm}$, i.e., the dimensions of mandibular canines of males and females have almost same dimension. This was in accordance with the study conducted by Gupta S et al. [16].

\section{CONCLUSION}

The canines show sexual dimorphism to a greater extent. This can be used as a tool for determining the sex of unidentified remains when most of the important features are damaged due to post-mortem damage. This is also resistant to post-mortem and natural stress and hence, is more reliable for sex determination.

\section{References}

1. Acharya $\mathrm{AB}$, Prabhu S, Muddapur $\mathrm{MV}$ (2011) Odontometric sex assessment from logistic regression analysis. Int J Legal Med 125: 199-204.

2. Kiesu JA (1990) Human adult odontometrics. In: The study of variation in adult tooth size. Cambridge University Press: 125-129.

3. Bilge Y, Kedici PS, Alakoç YD, Ulküer KU, Ilkyaz YY (2003) The identification of a dismembered human body: a multidisciplinary approach. Forensic SciInt 137: 141-146.

4. Lund H, Mörnstad H (1999)Gender determination by odontometrics in a Swedish population. J Forensic Odontostomatol 17: 30-34.

5. Reddy VM, Saxena S, Bansal P (2008) Mandibular canine index as a sex determinant: a study on a population of Western Uttar Pradesh. J Oral maxillofacsurg 12: 56-59.

6. Vodanovic M, Demo Z, Njemirovskij V, Keros J, Brkic H (2007) Odontometrics: a useful method for sex determination in an archaeological skeletal population. J ArchaeolSci 34: 905-913.

7. Mohammed QAR, Abdullah MA, Ashraf I, Khan N (1997)Dimorphism of mandibular and maxillary canine teeth in establishing identity. Saudi Dent J 9: 17-20.

8. Anderson DL, Thompson GW (1973) Interrelationships and sex differences of dental and skeletal measurements. J Dent Res 52: 431-438.

9. BOSSERT WA, MARKS HH (1956) Prevalence and characteristics of periodontal disease in 12,800 persons under periodic dental observation. J Am Dent Assoc 52: 429-442.

10. KROGH HW (1958) Permanent tooth mortality: a clinical study of causes of loss. J Am Dent Assoc 57: 670-675.

11. Patterson KB, Kogan SL (1985) Dental identification in woodbridge disaster. J Canad Dent Assoc 37: 301306.

12. Rao NG, Rao NN, Pai ML, Kotian MS (1989) Mandibular canine index--a clue for establishing sex identity. Forensic SciInt 42: 249-254.

13. Garn SM, Lewis AB, Kerewsky RS (1967) Buccolingual size asymmetry and its developmental meaning. Angle Orthod 37: 186-193

14. Ditch LE, Rose JC (1972) A multivariate dental sexing technique. Am J PhysAnthropol 37: 61-64.

15. Stroud JL, Buschang PH, Goaz PW (1994) Sexual dimorphism in mesiodistal dentin and enamel thickness. DentomaxillofacRadiol 23: 169-171.

16. Gupta S, Chandra A, Gupta OP, Verma Y, Srivastava S (2014) Establishment of Sexual Dimorphism in North Indian Population by Odontometric Study of Permanent Maxillary Canine. J Forensic Res 5:224 doi: $10.4172 / 2157-7145.1000224$ 